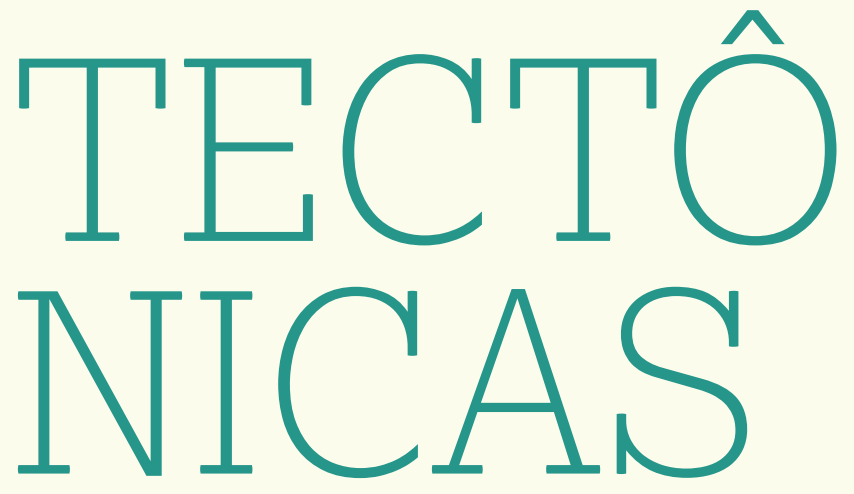

Do grego tektonikos, -ê, -ón. Arte de carpinteiro. Arte de construir edifícios. Estudo da estrutura da crosta terrestre. Placas tectônicas, criadas nas zonas de divergência, seu afastamento possibilita a explosão do magma. 



\title{
JAMIL \\ ALMANSUR HADDAD, \\ UM POETA À DERIVA
}

\author{
- CHRISTINA STEPHANO DE QUEIROZ
}

\section{RESUMO}

A história de Jamil Almansur Haddad, médico, poeta, ensaísta e tradutor brasileiro, foi marcada pela dificuldade dos críticos de entender e classificar sua poesia - em relação seja à literatura brasileira, seja às suas influências árabes. Filho de imigrantes libaneses, Haddad foi considerado figura controversa, mas publicou poesia, ensaios políticos e literários pelas principais editoras do país. Apesar dessa centralidade, o autor se tornou, hoje, desconhecido pelo público leitor. Assim, o objetivo deste artigo é delinear a trajetória intelectual do poeta, destacando suas transições e contradições com os movimentos literários brasileiros entre os anos 1930 a 1980.

Palavras-chave: Jamil Almansur Haddad, cânone, imigração árabe, Geração de 45, Modernismo, "fora de lugar".

\section{ABSTRACT}

The history of Jamil Almansur Haddad, a Brazilian doctor, poet, critic, essayist and translator, was marked by the difficulty of literary critics to understand and classify his poetry - whether in relation to the Brazilian literature, or in regard to his Arab influences. Son of Lebanese immigrants, Haddad was considered a controversial and polemical figure, but his poetry, and literary and political essays were published by the country's leading publishers. Despite of that, he suffered a gradual disappearance from the history of Brazilian literature. The purpose of this communication is to outline the poet's intellectual path, pointing out his transitions and contradictions with the Brazilian literary movements between 1930 and the 1980s.

Keywords: Jamil Almansur Haddad, canon, Arab immigration, 45's generation, Modernism, "out of place". 


\section{JAMIL ALMANSUR HADDAD, UM POETA À DERIVA}

F ilho de imigrantes libaneses, Jamil Almansur Haddad foi um médico, poeta, crítico, ensaísta e tradutor brasileiro que teve a trajetória marcada pela dificuldade dos críticos literários de entenderem e classificarem sua produção poética - em relação seja à literatura brasileira, seja às suas influências árabes. Personagem controvertido e polêmico, o poeta publicou ensaios literários e políticos de forma recorrente em jornais e revistas da grande imprensa, além de realizar traduções para grandes editoras - como Record e Brasiliense - pelas quais também publicou a maioria de seus livros de poesia. Assim, Haddad atuou como colaborador frequente de revistas como Pasquim, Diário de notícias, FoIha da manhã, O Estado de São Paulo e Revista do Arquivo Municipal de São Paulo, foi professor titular de Literatura Brasileira na Universidade de São Paulo (USP), deu aulas na Faculdade de Filosofia de Rio Preto e em centros universitários de Beirute (no Líbano) e em Damasco (na Síria), como parte de uma missão oficial organizada pelo Ministério de Relações Exteriores para estreitar os laços do Brasil com países do Levante. Foi o primeiro a traduzir Flores do Mal, de Charles Baudelaire, integralmente ao português, e introduziu as obras de Marquês de Sade no Brasil, quando o escritor maldito ainda era proibido de ser vendido em livrarias francesas.

Em maio de 1988, os jornais brasileiros que noticiaram a morte de Haddad com breves textos reverenciaram a figura controversa do grande intelectual e lamentaram seu gradativo esquecimento por parte da crítica. Nos livros dos principais teóricos da literatura nacional - como Antônio Cândido, Alfredo Bosi ou Afrânio Coutinho - há citações a respeito da importância de suas traduções e estudos críticos. No entanto, sua produção poética é taxada, frequentemente, de "paradoxal" ou "inclassificável"; de "passadista" e, ao mesmo tempo, "imoral".

De fato, há um aspecto ambivalente na trajetória do poeta, na medida em que, no âmbito da crítica, seu posicionamento se aproximou de correntes vanguardistas como os Noigandres, enquanto na poesia ele tinha um ideal ortodoxo, pelo menos no que diz respeito às questões formais. Porém, esse aspecto tradicional é contraposto por impulsos de transgressão, quando o poeta versa, por exemplo, sobre o erotismo de beduínas, amantes fantasmagóricas e sobre os hímens das virgens temas recorrentes em sua poesia. Conforme observado por críticos como Ivan Junqueira, essa contraposição dota os poemas de Haddad de uma estranheza e de um caráter paradoxal, como acontece com o poema "Erra, na alcova, um cheiro de almíscar e cânfora", de Alkamar, a minha 
amante, primeira obra poética do autor. Nesses versos, a preocupação com as rimas (cânfora / ânfora, nivoso / harmonioso, transparece / parece, sagrado / desfolhado, eterna / taberna etc.) antagoniza com as imagens pouco comportadas que o poema evoca: um gerânio desfolhado, gozo de esteta e de animal, corpo que é uma taça que referve e a orgia eterna na taberna:

Erra, na alcova, um cheiro de almíscar e cânfora...

O meu corpo nivoso,

neste momento, ostenta, o contorno harmonioso,

o contorno magnífico de uma ânfora!

Na ânfora do meu corpo o sangue transparece

como se fosse o vinho de um cálix sagrado.

De rosalbente, a minha carne até parece

leve, da trama de um gerânio desfolhado...

Feito para o teu gôso

de esteta e de animal,

meu corpo teporoso

é eurítmico e nevado, é estelante e anforal!

É uma ânfora o meu corpo! E é volutuoso o vinho

que espumeja, referve na taça que eu sou!

(...)

Na hora em que apareceres,

de cara poro

por que te chamo, por que te imploro,

hão de jorrar prazeres!

Os meus póros serão iguais

a bocais

de taças fraternais.

Ai! Amado, haurirás, na orgia mais enorme,

o vinho de loucura que em meu corpo dorme!

É longa a tua ausência assim como um caminho!

Vem, meu amante, vem! Meu corpo é ânfora,

meu sangue é vinho,

erra, na alcova, um cheiro de almíscar e cânfora. 
A orgia seja eterna!

Amante vem a mim! É a hora da taberna! ${ }^{1}$

[1] HADDAD, 1938, p. 91.

Tendo em conta o histórico mencionado, este artigo pretende delinear a trajetória intelectual do poeta, apontando suas passagens e contradições com os movimentos literários brasileiros - dos anos 1930 aos 1980 - e abordar sua relação com algumas ligas literárias árabes que se formaram na cidade de São Paulo.

\section{CONTRADIÇÕES COM O MODERNISMO}

Nascido na cidade de São Paulo em 1914, Haddad era filho do comerciante Melhen Haddad e da professora Sada Khouri Haddad que, ao imigrar ao país no final do século XIX, fundou um jornal feminista voltado à comunidade árabe instalada na cidade. Médico de formação carreira que, segundo ele, seguiu pela vontade de ascensão social da família - publicou dez livros de poesia, fez mais de 30 traduções para o português de obras do francês, árabe e inglês, organizou 20 antologias, além de outros ensaios e estudos críticos sobre literatura. Em seu espólio há, ainda, o manuscrito inédito de um livro de sonetos, além do segundo volume do que seria uma trilogia de 900 páginas escrita em francês e da qual somente a primeira parte foi publicada.

Com metade da obra poética escrita entre 1935 e 1951, Haddad participou ativamente das discussões a respeito dos novos ideais literários formulados para discutir o legado da Semana de Arte Moderna de 1922. Críticos como Alceu Amoroso Lima e Sérgio Milliet concordam que a primeira etapa moderna da poesia brasileira prevaleceu entre os anos 1922 e 1930, quando os artistas buscavam revoluções estéticas para se libertarem dos modelos do classicismo². Já a partir de 1930, os poetas se movimentaram para superar as fórmulas criadas na etapa anterior e o período é marcado por um caráter de transição, que se consolidou com o estabelecimento dos ideais da Geração de 45, ou Neomodernismo, conforme denominação de Lima. Para o crítico, há uma continuidade entre as fases poéticas. No entanto, se comparado ao Modernismo, o Neomodernismo é um movimento mais global do que pessoal, mais anônimo do que carismático, mais indefinido do que consciente, além de advogar por valores eternos e não modernos, de maneira que o "centro da gravidade (da poesia) se desloca do tempo para a natureza”3. Já os versos feitos sob os ideais da Geração de 45 são caracterizados pela volta a certo tipo de

[2] LIMA, 1959, p. 120 
[4] Cf. "Aramis Villarch entrevista Jamil Almansur Haddad" - Disponivel em http://www.millarch.org/ audio/jamil-almansur-haddad?page=38 - acesso em 20/4/2015.
No âmbito dessas discussões, Haddad publicou, em 1935, Alkamar, a minha amante, seu primeiro livro de poemas. A obra combina um imaginário orientalista à estética parnasiana e foi chamada, ao mesmo tempo, de passadista e imoral. Com Orações Negras, de 1937, livro premiado pela Academia Brasileira de Letras (ABL), o poeta passa a se valer da liberdade moderna e a insinuar preocupações sociais e políticas. Com o livro, o poeta afirmou que deixou de "(...) contemplar o próprio umbigo e passou a debruçar-se sobre o grande mundo e seus problemas", alinhando-se à tendência de poesia social que marcou a poesia nacional na década de 1930. Publicados pela Livraria Editora Record, os versos foram gestados durante os primeiros anos de atividade como médico, contendo imagens de artérias, leprosos, nervos, hemoptises, tuberculosos, sangue e chagas.

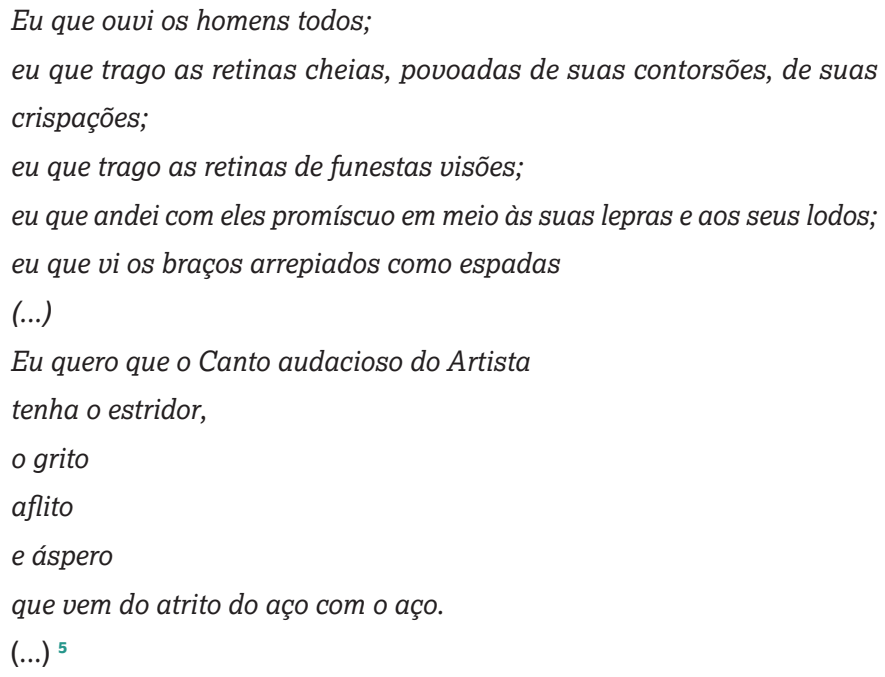

Na década de 1940, além de estrear como crítico e tradutor, Jamil escreveu dois outros livros de poesia, cujos imaginários líricos giram em torno dos eixos temáticos criados nas obras inaugurais. Assim, de um lado, ele seguiu explorando a atmosfera de fêmeas fantasmagóricas, principalmente na obra Poemas - Orações roxas - Novas orações negras Orações vermelhas, publicada em 1944 por Edições Cultura. Nela, saíram versos que evocam beduínas árabes, além de outros repletos de personagens femininas que vêm de outros mundos para seduzir o poeta com seus encantos funéreos, como no Canto elegíaco em louvor da amada: 
dos brancos círios longos queimando nas ecas...

tem a brancura

da sepultura...

A bem amada é clara, clara...

Há, em seu olhar cinéreo,

a claridade triste

dos fogos-fátuos do cemitério.

A bem-amada é cheia de aromas

tal como a campa da gente humilde,

sem lousas nem legendas,

mas que se enche de flores na primavera...

A bem-amada é cheia de luz infinita

tal como as ruínas

que o luar habita...

A bem-amada é cheia de silêncios...

Entra-se em seu amor, divina alma,

como se a gente entrasse na necrópole calma... ${ }^{6}$

[6] HADDAD, 1943, p. 21.

Primavera na Flandres, de 1948, como o próprio nome sugere, dialoga com a imagem da Europa devastada pela Segunda Guerra Mundial, e as preocupações se voltam aos diferentes países afetados pelo conflito global, como ocorre em Litania da França, Balada Londrina, Natal em Berlim e o Poema da angústia da Itália, em que a destruição das cidades italianas é lamentada por estátuas que se levantam dos túmulos, à meia-noite. Nesses versos, Julietas recobram vida para mostrar o luto fatal que a Musa não descreve, apaziguando dores e agonias e estancando a violência que fez o mármore das cidades chorar sangue:

Contam que à meia-noite, ao luar, em Verona que o Ádige, sonolento e pensativo, corta há um vulto de mulher que o túmulo abandona: Julieta vem chorar mesmo depois de morta.

Contam nas horas mortas que a vaga Veneza tem seu ar inundado de canções doridas... E o canal cismarento pensa com certeza que querem naufragar as gôndolas suicidas... 
Contam das catedrais, que certo receberam da angústia e do infortúnio o mais penoso dote, que nas naves augustas empalideceram, principiando a rezar na hora noturna, pela Itália sombria, a Itália taciturna, os santos imortais de Buonarrotti.

As dores como ferem! As chagas como gritam! Paira no ar desolado a voz das nostalgias. As vozes de Belini e Verdi ressuscitam para abafar a voz das agonias.

E o céu da Itália é azul! Mas que importam agora os fulgores da tarde e as músicas da aurona? Que importa a nuvem alva ou que se franja de ouro, se a nuvem vai ser chuva e no céu de amaranto ela dá a impressão de ser o embrião do choro, a semente nostálgica do pranto?

Como para atenuar a grande sombra espessa, esse luto fatal que a Musa não descreve. os Alpes muito além coroam a cabeça da mais imorredoura e alvinitente neve.

Lagos da Bela Itália! O Piano, o Idro, o Como, - Garda que sorri, o Lugano que reza, o Montorfano azul... Êsses lagos são como as lágrimas doridas que a Itália repreza.

E pela Isola Madre soturna e sonora das vozes virginais que choram pelos noivos, em vez das assucenas líricas de outrora florescem lírios roxos, ciprestes e goivos.

Nos museus onde há estatuas e brancor exangue, onde o silencio, flor de sombra e ocaso, medra, os mármores da Itália choram sangue, na hora em que os homens se fazem de pedra. ${ }^{7}$

Já em A Lua do Remorso, de 1951, considerado "surrealista" pelo próprio autor, prevalece um imaginário de delírios obscuros e versos 
carregados de um erotismo profano.

Ao ter estreado na poesia durante a segunda metade dos anos 1930, os críticos consideraram a obra de Haddad difícil de classificar, em parte, por se relacionar a um período de transição. No entanto, também notaram características paradoxais em seus livros, entre elas a liberdade de expressão moderna aliada a um imaginário romântico, o que dificultou sua aproximação aos diferentes momentos da poesia brasileira moderna.

Além disso, se por um lado a biografia de Haddad o aproxima da Geração de 45 - já que ele participou ativamente de grupos e revistas produzidas com o intuito de difundir os ideais do movimento - por outro, os principais críticos vinculados ao período, entre eles Milton Godoy de Campos, distanciaram-no das tendências gerais da poesia de 45. Assim, esses especialistas consideraram que os autores estreantes antes de 1944 ainda estavam presos ao clima literário da Semana de Arte Moderna, justificativa que, em um primeiro olhar, não pode ser aplicada à obra de Haddad.

Ao fazer uma análise genérica e sucinta do perfil do poeta, o editor da Revista Brasileira de Poesia, Domingos de Carvalho da Silva, considerou que ele "jamais foi poeta de escola", mas afirmou que seus versos se opõem ao objetivismo típico dos ideais de 1922, por trabalharem um lirismo amoroso subjetivo. Silva vincula Haddad aos autores da segunda etapa modernista, ou geração de 30, grupo do qual, segundo a opinião do crítico Ivan Junqueira, o autor caminhou totalmente à deriva ${ }^{9}$. A jornalista Helena Silveira, que foi esposa de Haddad durante dez anos, reiterou que o poeta viveu "ilhado em uma solidão dilacerante" ${ }^{10}$ e que o Modernismo passou ao largo de seus versos, posição compartilhada pelo autor, conforme depoimentos publicados em jornais ${ }^{11}$.

Essa visão de distanciamento extremo da poética moderna, no entanto, não faz parte das análises de Sérgio Milliet. Para o crítico, a liberdade moderna está presente na obra de Haddad, entre outros momentos, quando ele adota um discurso que ignora os freios da rima e da medida silábica: “(...) da liberdade moderna, Jamil não se aproveitou para cantar, mas sim para discursar mais um pouco, para esparramar, já agora sem os freios da rima ou da medida silábica"12.

No entanto, em relação aos poetas de 1930, além do elo cronológico (Jamil estreou na poesia em 1935), outros aspectos que o aproximam da geração são a poesia de viés político e social que se faz presente, principalmente, em Orações Negras. No livro, aparecem preocupações com a realidade do Brasil, como se observa no já citado Primeiro poema da vida:

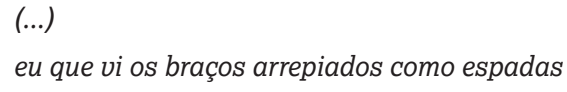

[8] SILVA, 1949, p. 53.

[9] JunqueiRa, 2008, p.17.

[10] SILVEIRA, 1977, p. 37.

[11]

[12] MilLiet, 1981, p. 49. 


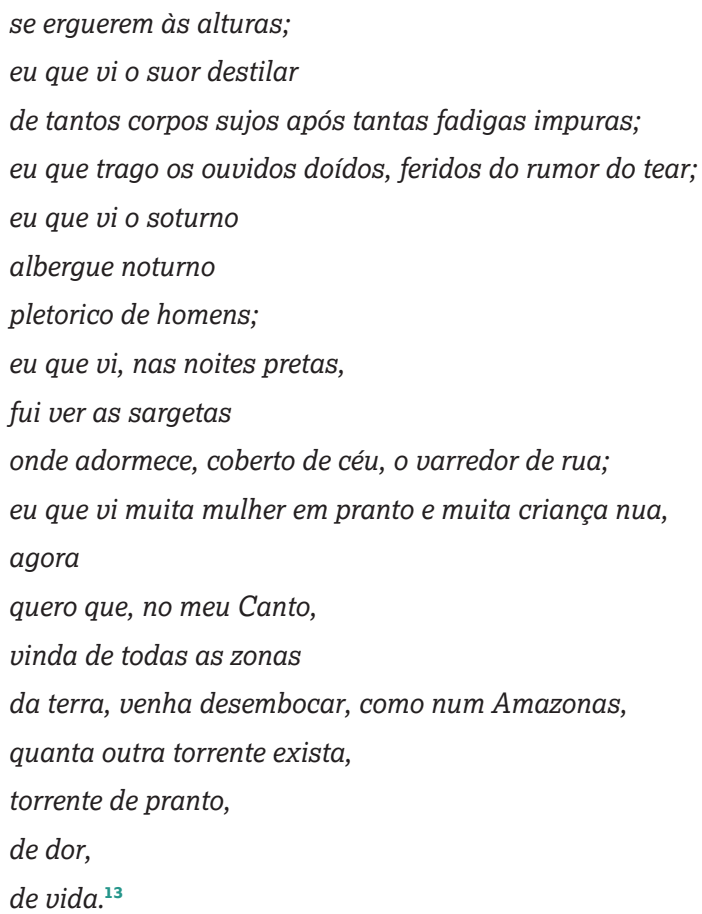

\section{INCOERENTE, MAS AUTÊNTICO}

Nos anos 1950, as discussões centradas no Movimento Modernista cederam espaço ao surgimento de novas vanguardas na cena literária brasileira, entre elas o concretismo, o poema-praxis e o poema-processo. Dessa forma, se por um lado o concretismo de 1956 defendia o abandono do verso em favor de uma sintaxe espacial, fazendo oposição ao intimismo

[14] Bosı, 2006, p. 476.

[15] Holanda, 2004, p. 110 a 111. da Geração de $45^{14}$, o poema-práxis de 1962 emergiu como alternativa ao didatismo populista dos Centros de Cultura Popular, ligados ao Partido Comunista, e também ao tecnocracismo dos concreto ${ }^{15}$. Dessa forma, o poema-práxis absorveu criticamente a modernidade vanguardista e o engajamento comunista. Já o poema-processo, de 1968, foi considerado uma radicalização dos ideais concretos, pois se apoiava na construção visual dos poemas e na tática de performances.

Como diretriz geral, Heloísa Buarque de Hollanda opina que, na década de 1960, não havia espaço para o artista de minorias e a arte era vista como caminho à tomada de poder. O poeta, por sua vez, escrevia para multidões e se preocupava em ter clareza para ser entendido pelo povo. Com a eclosão do Tropicalismo, em 1967, há um rompimento com esse tom grave de engajamento e a identificação passa a ser com as 
minorias - e não mais com os proletários. Marcados por uma atitude avessa às ortodoxias, os tropicalistas rejeitavam o discurso burocrático do Partido Comunista, tendência comum à chamada geração marginal dos anos 1970, também marcada por uma postura anti-intelectual.

Por outro lado, diferente das vanguardas como o concretismo e o poema-processo, os poetas marginais não defendiam o experimentalismo, sinalizando uma rejeição à técnica e à ideia do novo. Dessa forma, o poema passou a ser visto como o registro ou o desejo imediato da ação - e não da reflexão - e apresentava caráter de momentaneidade ${ }^{16}$. Durante a década de 1970, proliferam-se as artes com projeções coletivas, como o cinema e os festivais de música, e a ficção sofre o impacto do boom jornalístico, o que resultou no desdobramento dos gêneros da escrita e abriu espaço para romances que parecem reportagens, contos que não se distinguem de poemas ou crônicas, entre outros ${ }^{17}$.

Beatriz Vieira de Moraes ${ }^{18}$ avaliou que, após o predomínio de movimentos de contracultura nos anos 1960, o AI-5 silenciou a voz dos rebeldes e gerou um vazio cultural. Isso porque trabalhadores e intelectuais que participaram de movimentos de resistência estavam desorientados e desmoralizados devido à desestruturação de suas lideranças, que foram presas, mortas ou exiladas. No marco de uma fase de reafirmação do regime ditatorial, crescimento econômico e repressão política, Vieira lembrou que nos anos 1970 há tendências de constituir uma cultura subjetiva, pois, conforme a vida pública se tornava cada vez mais difícil, a sociedade se voltava à esfera privada: “(...) Era preciso encontrar um ponto intermediário entre ser revolucionário e ser apolítico. (...) Buscava-se uma auto-coerência que impedisse, ou tentasse, a fragmentação interna" () ${ }^{19}$. No entanto, a estudiosa opinou que as reações subversivas aumentavam conforme o regime se endurecia e, nesse caminho, a poesia era vista como forma de resistência ao sufoco do momento.

Anos depois de A Lua do Remorso, de 1951, Haddad publicou três livros, além de escrever um quarto - Sonetos do artífice, inédito - que recebeu um prêmio da Academia Paulista de Letras, em 1960, conforme certificado encontrado em seu espólio. Destoando das outras obras da segunda fase, marcadas por aspecto politizado, os sonetos inéditos apresentam caráter amoroso e, a exemplo das obras da primeira etapa, aliam um lirismo romântico a recursos modernistas.

O poeta que escreve para o povo e concebe a palavra como instrumento à tomada de poder é a voz central em Romanceiro Cubano, de 1960 e que, inspirado no Romancero Gitano, de Federico García Lorca, canta a necessidade de participação política por meio de uma visão otimista, na qual a revolução cubana desempenha papel central. Para Alfredo Bosi ${ }^{20}$,

[16] IBIDEM.

[17] CÂNDIDo, 1987, p. 245.

[18] VIEIRA, 2007, p. 201.

[19] VIEIRA, 2007, p. 56.

[20] Bosı, 2006, p. 476. 
[21] Morre o poeta e psiquiatra Jamil Almansour Haddad. São Paulo: O Estado de São Paulo, 5 de maio de 1988, p. 17.

[22] IBIDEM,

[23] M.C.C, Aviso aos navegantes: a poesia bilíngue de Jamil Almansour Haddad. São Paulo: Jornal Folha de São Paulo, 13 de agosto de 1980, p. 125.

[24] IBIDEM. junto a outros autores da década, a obra de Haddad define uma das componentes centrais do clima literário dos anos 1960, ao abordar questões sociais por meio de uma voz preocupada em ser entendida por multidões.

A exemplo do que aconteceu com outros artistas e intelectuais, o golpe militar afetou a vida e a produção poética de Haddad. Em depoimento no jornal Folha de São Paulo², ele explicou que, a partir de 1966, sentiu-se obrigado a fazer versos também em francês, devido à censura e à dificuldade crônica de publicar poesia no Brasil. Com isso, de 1963 a 1977, o autor deixou de publicar - mas não de escrever. E o resultado desses anos de clausura e isolamento é o singular livro Aviso aos navegantes ou A bala adormecida no bosque - O primeiro livro das suratas, concluído em 1976, e que evocou ideais subversivos em um momento no qual a ditadura militar procurava reafirmar-se.

Ao percorrer histórias relacionadas a movimentos guerrilheiros em países latino-americanos, a guerra do Vietnã, a ocupação da Palestina, a revolução cubana, o programa bolchevista, entre outras, o livro trata de insurreições e subversivos, denunciando injustiças sociais e políticas. Ao abordar revoluções e líderes de diferentes épocas e países, rompe fronteiras nacionais e temporais e cria uma atmosfera de caos da qual emerge a essência da experiência libertária. A rebeldia que prega no discurso se reflete na forma desordenada do livro, que contém poemas com versos livres e rimados, citações alheias, trechos de livros, entrevistas e notícias, além de notas de rodapé, que podem reforçar o caráter verídico do que retrata ou ampliar as possibilidades de associação. Haddad incorpora, assim, a fala de outros ao seu discurso, criando um coro multiforme que clama pela insurreição.

Em depoimento ${ }^{22}$, Haddad contou que, prevendo a ação da censura no Brasil, reescreveu $A$ bala adormecida no bosque em francês. Com isso, Avis aux navigateurs - Le premier livre dês Sourates saiu em 1977, na França, pela editora François Maspero. O livro recebeu elogios de escritores e críticos da reputação de Tahar Ben Jelloum e foi adotado em liceus franceses. Em entrevista ${ }^{23}$, Haddad afirmou que a repercussão naquele país superou suas expectativas, ao ser bem recebido tanto pela direita radical como pelos anarquistas, ou seja, convencendo-o de que: “(...) apesar do conteúdo político dos poemas, eu conseguira alcançar uma linguagem no sentido universal"24.

Em meio às ideias dos críticos que enxergaram na obra um tom de imprecação característico da linguagem profética, Haddad afirmou que o livro está carregado de um islamismo espiritual ligado às suas origens, embora sua família libanesa seja cristã: “(...) Sinto que (o islamismo espiritual) não é uma mera influência cultural, mas algo que está integrado à minha 
personalidade mais íntima, como se toda a sucessão infinita dos meus antepassados tivesse colaborado nesta obra"25. Nesse sentido, vale mencionar que Haddad se converteu ao islamismo por uma questão de identidade literária, conforme jornalista que o entrevistou na ocasião do lançamento ${ }^{26}$.

Em 1980, três anos após ser publicado na França, o livro saiu no Brasil pela Editora Ciências Humanas, fundada pelo catalão Raul Mateos Castell. Com o lançamento de ambas as versões, o nome de Haddad voltou aos jornais que, mais uma vez, acusaram a dificuldade de classificação de sua poesia.

Como tônica geral das resenhas, destacou-se, mais uma vez, o caráter social da poesia de Haddad. Entre os críticos brasileiros, Alceu Amoroso Lima parece ter apreendido a obra de forma mais coerente, ao afirmar que o livro está sintonizado a uma tendência pós-moderna da poesia da época, que opõe uma noção de "planetarismo" à ideia de nacionalismo ou regionalismo vigente no Modernismo. Para Lima, apesar de a palavra revolução ter adquirido um tom pejorativo no imaginário brasileiro - em função de sua conexão ao discurso burocrático do Partido Comunista - Haddad dá um sentido inédito a ela, ao usá-la para defender uma revolução social que é, também, espiritual.

Com $A$ bala adormecida no bosque - que seria o primeiro volume da mencionada trilogia de 900 páginas escrita em francês - Haddad parece atingir a plenitude de sua poesia, consolidando a construção de uma lírica própria. Essa via parece representar a reinvenção da poesia erótica carregada de culpa e dos versos engajados que atraíram e desviaram a atenção dos críticos desde os anos 1930. Com isso, o narrador lírico deixa de ser o cronista dos injustiçados ou o libertino arrependido - que parte para os clichês orientalistas para poder se entregar a atividades pecaminosas - transformando a voz poética no grito do guerrilheiro que é também profeta e místico universal.

\section{POESIA ORIENTAL?}

Para contextualizar a trajetória intelectual de Haddad, também é preciso mencionar a proximidade biográfica que ele teve dos poetas da imigração árabe que, radicados em São Paulo, fundaram a Liga Andalusina, em 1933. Conforme Sobhi Habchi ${ }^{27}$, os poetas da Liga queriam libertar a literatura árabe de entraves e cadeias que limitavam seu desenvolvimento, além de funcionarem como uma ponte entre os países árabes e as nações do continente americano. Apesar de ter frequentado os círculos desses intelectuais, Haddad não participou de atividades
[25] IBIDEM.

[26] Entrevista com Moacir Amâncio, realizada na Universidade de São Paulo, em junho de 2013. 
[28] VIEIRA, 1943, p.195;

[29] BAstide, Roger, "As raízes árabes da poesia de Jamil Almansur Haddad", Exclusividade da Inter-Americana para a Folha da Manhã. São Paulo: Estado de São Paulo, p. 3. O recorte de jornal encontrado no espólio do poeta não apresenta referências quanto à data de publicação. Por se referir somente aos dois primeiros livros, supõe-se que o artigo tenha sido publicado em meados dos anos 1940. de produção poética e tradução dos escritores da Liga Andalusina que, diferentemente do autor brasileiro, escreviam unicamente em árabe. Sua presença entre os circuitos de escritores árabes radicados no Brasil parece ter sido mais frequente após o golpe militar, quando ele verteu do árabe obras de poetas da Liga da Pena (fundada em 1968), entre elas Brisas do Líbano, de Felipe Lutfalla (1970) e Ausência, de José Fakhoury (1975). Outra referência biográfica em relação aos escritores de origem árabe foi a proximidade que teve a Assis Féres, poeta de origem libanesa e editor da revista Laiazul, publicada no Chile e no Brasil, desde meados dos anos 1930 até meados dos anos 1960.

Nesse caminho, também é preciso sinalizar as contradições dos críticos ao captarem o viés "oriental" ou "árabe" da poesia de Haddad. Um deles foi o escritor José Geraldo Vieira que, no posfácio de Poemas (1943), defende a existência de uma lírica oriental em Alkamar, a minha amante, em que Haddad teria feito "uma descida longitudinal da raça" Vieira afirma, por outro lado, que Orações negras (1939) contém poemas "atlânticos e ocidentais", concluindo que o poeta estreou com uma obra de viés oriental, migrando para um imaginário ocidentalizado em seu segundo trabalho.

Essa ideia é contestada por Roger Bastide em um artigo de 1940 e no qual o sociólogo francês argumentou que as raízes de um repositório de versos não estão nos assuntos tratados, mas na "exteriorização lírica da alma" 29 . Ele opõe-se aos críticos que, à maneira do mencionado Vieira, defenderam a existência de um movimento de nacionalização de Alkamar a Orações negras, ao afirmar que esses estudiosos ficaram "na superfície colorida dos poemas". Bastide argumentou, assim, que apesar de abordar temas do Oriente, Alkamar é construído através das normas estéticas do romantismo e do parnasianismo brasileiros. Ou seja, é vivido por meio de uma visão ocidental. Mas, apesar de acertar nesse comentário, Bastide usou exemplos questionáveis para defender a "arabização" de Haddad em Orações negras. Para justificar seu argumento, comentou que, um dos momentos no qual a herança árabe emerge na obra, ocorre quando há uma comunhão entre o sofrimento do poeta solitário e a dor dos infelizes. Para Bastide, essa associação remete à nostalgia de uma harmonia perdida (com a terra dos antepassados), algo que é questionável, na medida em que também pode ser vista em relação ao sentimento cristão de compaixão com os desfavorecidos.

Bastide opinou que a sensibilidade libanesa de Haddad se manifesta, ainda, quando o narrador lírico trata de mulheres tuberculosas internadas. O sociólogo lembrou que a esterilidade dessas mulheres foi tema recorrente na poesia dos simbolistas franceses, que as descreviam como 
pessoas interditadas ao amor. No entanto, diferente deles, ele argumentou que Haddad retrata essas figuras femininas "como tendas ao nômade fatigado" e aptas ao amor, algo que seria o reflexo de uma visão sensual típica dos orientais: "Somente um oriental seria capaz de, em lugar de se afastar com horror, transformar a hemoptise numa flor que abre suas pétalas vermelhas sobre a brancura dos lençóis ou sobre a nudez estelar de um corpo agonizante"30. Sem justificar os motivos pelos quais atribui caráter árabe ou oriental a esse olhar erótico presente nos versos, Bastide acaba por cair no mesmo erro de seus colegas, ao se apegar a clichês infundados para construir seu argumento a respeito das raízes árabes de Haddad.

\section{UMA BALA ADORMECIDA NO BOSQUE}

Oriental ou ocidental, passadista ou imoral, modernista ou neomodernista, poeta da geração de 30 ou da Geração de 45, Haddad parece ter circulado por vários ambientes, sem limitar-se a nenhum deles. Em um autor no qual os paradoxos falam mais alto do que as afiliações e que, em muitos momentos, teve de defender o direito à incoerência para tratar de opções estéticas e literárias ${ }^{31}$, suas obras parecem não se encaixar, mesmo quando consideradas parte do clima literário da época. Esse é o caso, por exemplo, de Romanceiro Cubano que, apesar do didatismo engajado, também evoca um ideal transnacional que destoa do discurso nacionalista de outras produções do período. Esse isolamento de Haddad ganhou um impulso irreversível com a eclosão da literatura marginal, no final da década de 1960 - cujo anti-academicismo se opõe à erudição do seu último livro - e culminou com sua decisão de escrever seus derradeiros versos em francês.

Marcada por elementos românticos e simbolistas, pelo uso de imagens orientalistas e outras que fazem jogos de contrastes, além de um aspecto declamatório e certo grau de engajamento, a trajetória poética de Jamil foi desvinculada pelos críticos das tendências gerais que caracterizaram outros poetas das décadas. Porém, apesar dessa aparente desconexão estética na literatura que produzia, Jamil estava bem posicionado na cena cultural do seu tempo, ao publicar poesias, ensaios e traduções pelas grandes editoras, escrever periodicamente a veículos da imprensa e frequentar círculos literários como o dos poetas da Geração de 45. Assim, como intelectual, consolidou uma presença para além dos limites da colônia sírio-libanesa estabelecida em São Paulo.

E, apesar de terem sido lidos, em muitos momentos, na chave de um poeta "fora de lugar", os quatro primeiros livros de Jamil mostram apro-
[30] Idem;

[31] "Pede-se a minha experiência sobre tradução de poesias. Justifica-se: minhas excursões por esses meandros são longas, numerosas, polimorfas, quando não contraditórias: Omar Khayyam, Cântico dos Cânticos, Petrarca, Bocaccio, Carducci, Safo, Anacreonte, Kipling, Verlaine, Baudelaire e uma infinidade de coisas no limbo do ineditismo (...). Venço, antes de mais nada, uma resistência psicológica: a pouca disposição em falar de mim mesmo. Mas o que fazer se os outros não falam? A questão não é de somenos: uma abolição ou atenuação da crítica pode levar à autocrítica (...). Falei no caráter às vezes contraditório do meu elenco de obras traduzidas: não há nada de afim entre Omar Khayyam e Rudiard Kippling. Contradições também de mim comigo mesmo: Kipling é poeta do imperialismo e eu nada tenho que ver com a história (ou a História). Reclamo, portanto, o direito à incoerência" (HADDAD, Jamil Almansur, "Confissões de um tradutor de poesia". São Paulo: Trad. e Comun. n.2, 97-108, março de 1983, p. 97. 
[32] JunquelRA, 2008, p.7. ximações e afastamentos das tendências líricas dos anos 1930 a 1950. Em relação aos poetas de 1930, além do elo cronológico (Jamil estreou na poesia em 1935), outros aspectos que o aproximam da geração são a poesia de viés político e social que se faz presente, principalmente, em Orações Negras. Além desse, o impulso de repensar a liberdade formal propiciada pelo Modernismo, rechaçando a estética da ruptura e da agressão às normas da língua culta ${ }^{32}$, é outra evidência dessa aproximação.

Porém, ao mesmo tempo, Jamil recorreu a elementos da poesia romântica e simbolista, criando um imaginário de fantasia, povoado por personagens e situações irreais, onde estátuas se levantam dos túmulos para chorar a destruição da guerra e amantes surgem das toalhas brancas dos altares. Além disso, seus versos parecem estar desprovidos da preocupação em criar uma identidade literária nacional, característica que remete à lírica cosmopolita dos poetas simbolistas, mas também ao projeto de literatura brasileira concebido pelo grupo dos Noigandres.

Além da sua própria biografia, o apuro formal, as preocupações existenciais e o lirismo amoroso subjetivo são características que o aproximam dos poetas de 45. Apesar dessas afinidades, há elementos que o distanciam, conforme atestou Milliet, sendo um deles o aspecto declamatório e grandiloquente de versos como: "Dançam, flutuando à brisa, os teus cachos desnastros... / Que dança e que esplendor! Teu corpo que flexiona,/ todo clareado, miracular,/ me dá a sensação de incrível dança dos astros!”.

Outro aspecto que marcou a trajetória do poeta durante essas décadas foi o uso de imagens orientalistas de beduínas e desertos e, também, a leitura que a crítica fez dele como "poeta oriental" - mesmo ele sendo brasileiro e, até então, interessado pelas tendências de movimentos locais, como o romantismo e o simbolismo. Evidência desse envolvimento é que mesmo os elementos "orientais" da sua poesia são mediados por uma visão romântica, que transforma características da cultura árabe em imagens exóticas. Também devido a esse uso, ele foi considerado poeta de vertente árabe por críticos que, à época, confundiram imagens orientalistas com o que denominaram com a vaga caracterização de "poesia oriental".

No entanto, apesar do movimento geral de considerá-lo como um poeta "estrangeiro" ou "exógeno" - seja em relação à sua nacionalidade, como em relação à falta de enquadramento nos movimentos literários fica evidente que suas preocupações líricas estavam imersas na estética e nos debates sobre a história e os rumos da literatura brasileira. Assim, ele escreveu poesia de caráter social, afinado com as tendências dos poetas de 1930; procurou recriar a estética que ficou como legado da poesia modernista; discutiu a identidade poética nacional, a partir do lugar do Barroco na história; e, ainda, contestou a visão de que os poetas 
românticos foram importantes, principalmente, porque criaram um projeto de nação brasileira a partir da literatura, argumentando que a relevância deles reside no fato de fazerem parte de uma linhagem universal de poetas malditos. I 


\section{BIBLIOGRAFIA}

BOSI, Alfredo. História concisa da literatura brasileira. São Paulo: Cultrix, 2006

CÂNDIDO, Antônio. A educação pela noite e outros ensaios. São Paulo: Ática, 1987.

HABCHI, Sobhi. Les fils d'Orphée - du Mont Liban aux Amériques. Paris: Libraire d'Amérique et d'Orient, 2004.

HADDAD, Jamil Almansur. Confissões de um tradutor de poesia. São Paulo: Trad. e Comun. n.2, 97-108, março de 1983.

HADDAD, Jamil Almansur. Alkamar, a minha amante. (São Paulo, Livraria Editora Record, 1938)

HADDAD, Jamil Almansur. Orações negras. (São Paulo: Livraria Editora Record, 1939).

HADDAD, Jamil Almansur. Poemas. (São Paulo, Edições Cultura, 1943).

HADDAD, Jamil Almansur. Primavera na Flandres. (São Paulo, A Bolsa do Livro Editora, 1948).

HADDAD, Jamil Almansur. A Lua do Remorso. (São Paulo, Livraria Martins Editora, 1951)

HADDAD, Jamil Almansur. Romanceiro cubano. (São Paulo: Brasiliense, 1960).

HADDAD, Jamil Almansur. Romance do Rio da Guarda ou O Governador e os mendigos. (São Paulo: Editora Fulgor, 1963).

HADDAD, Jamil Almansur. Sonetos do artífice. Inédito.

HADDAD, Jamil Almansur. Aviso aos navegantes ou A bala adormecida no bosque - O primeiro livro das Suratas. (São Paulo: Livraria Editora Ciências Humanas, 1980).

HADDAD, Jamil Almansour. Avis aux navigateurs - Le premier livre des sourates. (Paris: Librairie François Maspero, 1977). 
HOLANDA, Heloisa Buarque de. Impressões de viagem. São Paulo: Aeroplano, 2004.

JUNQUEIRA, Ivan, Roteiro da poesia brasileira, anos 30. São Paulo, Global Editora, 2008.

LIMA, Alceu Amoroso. Quadro sintético da literatura brasileira. Rio de Janeiro: Livraria Agir Editora, 1959.

MILLIET, Sérgio. Diário crítico, volume II, Janeiro de 1943. São Paulo: Edusp, 1981.

SILVA, Domingos de Carvalho. "Sobre Jamil Almansur Haddad” in: Revista Brasileira de Poesia. São Paulo: fevereiro de 1949.

SILVEIRA, Helena, “Um cavaleiro solitário da poesia brasileira” in: Jornal Folha de São Paulo. São Paulo: 22 de novembro de 1977.

VIEIRA, José Geraldo. "O Boabdil exilado" in: Haddad, Jamil Almansur. Poemas. São Paulo: Edições Cultura, 1943.

VIEIRA, Beatriz de Moraes. A palavra perplexa: experiência histórica e poesia no Brasil nos anos 70, Tese de doutorado. Rio de Janeiro: Universidade Estadual Fluminense, 2007.

\section{JORNAIS}

O Estado de São Paulo, 5 de maio de 1988.

Folha de São Paulo, 13 de agosto de 1980.

Exclusividade da Inter-Americana para a Folha da Manhã. São Paulo: Estado de São Paulo (espólio).

\section{ENTREVISTAS}

Moacir Amâncio, realizada na Universidade de São Paulo, em junho de 2013. 